\title{
Contribution to the smut fungi of Africa. 1
}

\section{Teodor T. Denchev* \& Cvetomir M. Denchev}

Institute of Biodiversity and Ecosystem Research, Bulgarian Academy of Sciences, 2 Gagarin St., 1113 Sofia, Bulgaria

Received 23 February 2016 / Accepted 3 March 2016 / Published 6 March 2016

Denchev, T.T. \& Denchev, C.M. 2015. Contribution to the smut fungi of Africa. 1. - Mycobiota 6: 2127. doi: 10.12664/mycobiota.2016.06.02

Abstract. Four species of smut fungi are reported for the first time from the following areas: Melanopsichium pennsylvanicum from Egypt and Madagascar, Sporisorium foveolati from the Canary Islands and Somalia, Sporisorium lanigeri from Somalia, on a new host, Cymbopogon pospischilii, and Urocystis corsica from the Canary Islands. Echinochloa stagnina is a new host of Ustilago trichophora in Africa (based on a record from Zambia).

Key words: Africa, Canary Islands, Egypt, Madagascar, Melanopsichium, Poaceae, smut fungi, Somalia, Sporisorium, taxonomy, Urocystis, Zambia

\section{Introduction}

In regard to the smut fungi, Africa is one of the most poorly studied continents of the world (Vánky et al. 2011). The present series is devoted to accumulation of new data on the smut fungi of Africa. In the first part, we report new records of five species.

\section{Materials and methods}

Dried specimens from the herbaria of the Botanic Garden and Botanical Museum BerlinDahlem (B) and the Royal Botanic Gardens, Kew (K), and the Herbarium Ustilaginales Vánky (H.U.V.), kept at the herbarium of the Queensland Department of Agriculture and Fisheries, Brisbane (BRIP), were examined under light microscope (LM) and scanning electron microscope (SEM). For LM observations and measurements, spores or spore balls were mounted in lactoglycerol solution ( $\mathrm{w}: \mathrm{la}: \mathrm{gl}=1: 1: 2$ ) on glass slides, gently heated to boiling point to rehydrate the spores, and then cooled. The measurements of

*Corresponding author: e-mail: ttdenchev@gmail.com 
spores are given as min-max (mean \pm 1 standard deviation). For SEM, spores or spore balls were attached to specimen holders by double-sided adhesive tape and coated with gold in an ion sputter. The surface structure of the spores was observed and photographed at 10 $\mathrm{kV}$ accelerating voltage using a JEOL SM-6390 (Figs 8, 11, 12, 15, 16) and JEOL JSM5510 (Fig. 7) scanning electron microscopes. The description of spore ornamentation is in accordance with Denchev et al. (2013). The height of the wall ornaments (warts and spines) was measured in SEM. The descriptions of smut fungi given below are based entirely on the specimens examined.

\section{Taxonomy}

Melanopsichium pennsylvanicum Hirschh., Notas Mus. La Plata, Bot. 6(32): 149, 1941.

Figs 1, 2

Sori destroying some flowers in the inflorescence, forming very hard, irregularly lobbed, purplish black galls. Spores variable in shape, subpolyhedral, irregular, subglobose, broadly ellipsoidal, ellipsoidal, irregularly elongated or ovoid, $(6-) 7-12.5(-15.5) \times(5.5-) 6.5-$ $9(-10)(10.0 \pm 1.4 \times 7.7 \pm 0.7) \mu \mathrm{m}(\mathrm{n} / 3=150)$, light to medium yellow-brown; spore wall slightly irregular, $0.6-1.0 \mu \mathrm{m}$ thick, minutely echinulate; some spores covered by an inconspicuous hyaline sheath.

Specimens examined - On Persicaria senegalensis (Meisn.) Soják (Polygonum senegalense Meisn.): EGYPT, sin. loc., 2 Dec 1927, leg. N.D. Simpson, no. 5651 (K); EGYPT, El Marq, 14 Dec 1927, leg. N.D. Simpson, no. 5516 (K); MADAGASCAR, Fort Dauphin, April, leg. G.F. Scott Elliot, no. 2384 (K).

Distribution: on Persicaria spp. (Polygonaceae). In Africa known on Persicaria barbata (L.) H. Hara, P. lapathifolia (L.) Delarbre, P. senegalensis, and Persicaria sp. from Congo, Ethiopia, Kenya, S. Africa, Tanzania, Uganda, Zambia, and Zimbabwe (Vánky et al. 2011). Melanopsichium pennsylvanicum is reported here for the first time from Egypt and Madagascar.

Sporisorium foveolati (Maire) Vánky, Mycotaxon 33: 367, 1988.

Figs 3-8

Sori destroying the whole inflorescence, partly hidden by the uppermost leaf sheath, covered by a thick, rusty brown peridium that ruptures irregularly, exposing a single, flageliform, slightly tapering, not ramified columella with shallow longitudinal furrows. The columella is surrounded by a semi agglutinated to agglutinated, blackish brown mass of spores and sterile cells. Sterile cells usually single, sometimes in small groups, broadly ellipsoidal, subglobose, globose or irregular, often collapsed, (12-)13-22(-25) $\mu \mathrm{m}$ long, larger than the spores, hyaline or subhyaline; wall 1.2-3.0 $\mu \mathrm{m}$ thick, smooth. Spores subpolyhedral or irregular, sometimes broadly ellipsoidal, subglobose, ellipsoidal or ovoid, often slightly flattened on a few places, (8.5-)9-12(-13) $\times(8-) 8.5-11(-11.5)$ $(10.7 \pm 0.6 \times 9.6 \pm 0.6) \mu \mathrm{m}(\mathrm{n}=200)$, medium reddish brown; wall slightly unevenly thickened, $0.6-1.1 \mu \mathrm{m}$ thick, minutely echinulate, spore profile slightly affected. In SEM minutely echinulate, spinules up to $0.2(-0.3) \mu \mathrm{m}$ high; spore surface punctate between the spinules. 


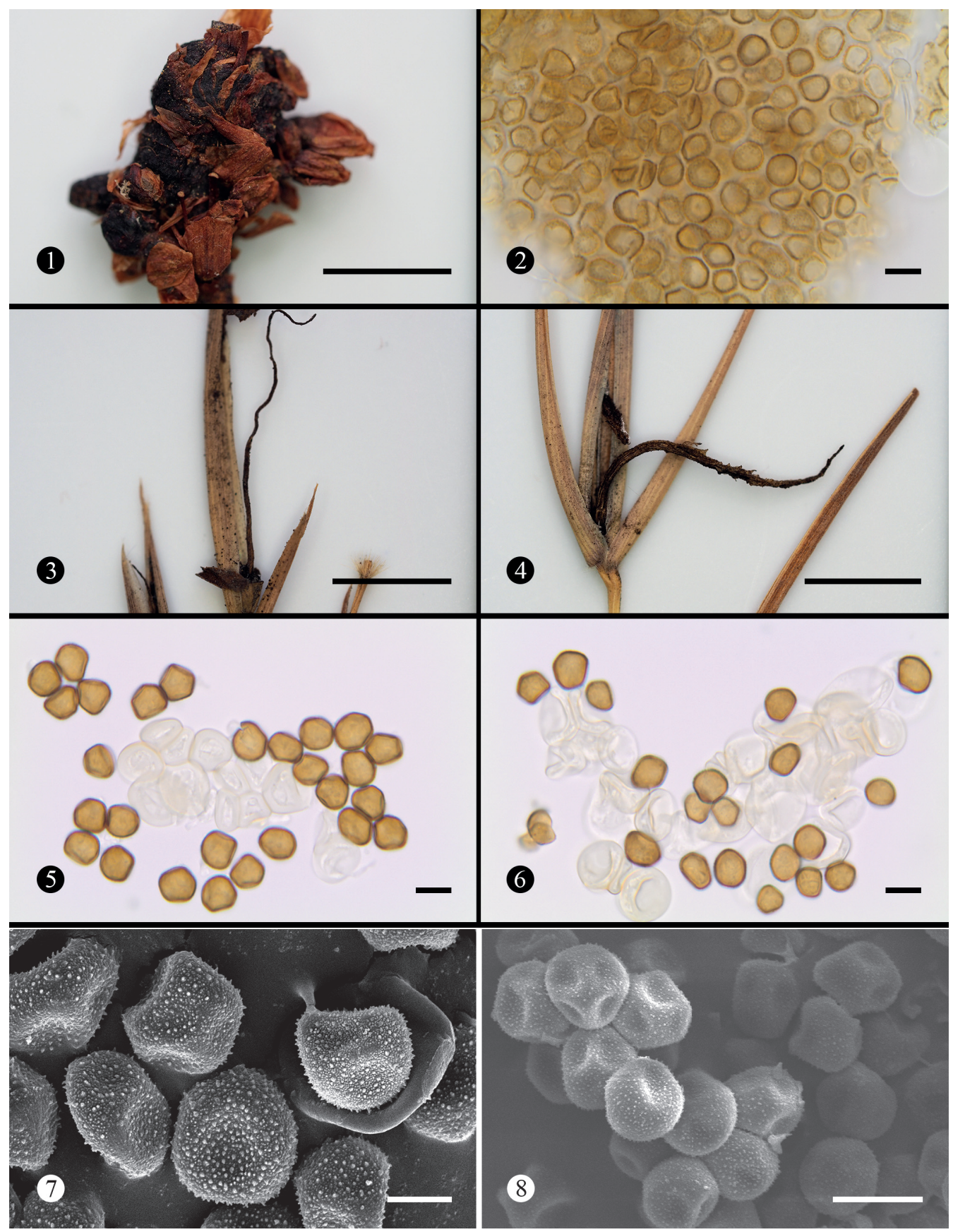

Figs 1, 2. Melanopsichium pennsylvanicum (K). 1. Habit. 2. Spores in LM. Figs 3-8. Sporisorium foveolati (3, 5, 7 - H.U.V. 13 201, isotype; 4, 6 - B, Canary Islands; 8 - B, Somalia). 3, 4. Habit. 5, 6. Spores and sterile cells in LM. 7, 8. Spores in SEM. Scale bars: 1, 3, $4=0.5 \mathrm{~cm}, 2,5,6,8=10 \mu \mathrm{m}, 7=5 \mu \mathrm{m}$ 
Specimens examined - On Dichanthium foveolatum (Delile) Roberty: CANARY ISLANDS, Island of Gran Canaria, Maspalomas, 29 Feb 1992, leg. H. Scholz (B, host plant as Eremopogon foveolatus (Delile) Stapf); SOMALIA, S of Elayo, 14 Mar 1988, leg. B. Gabriel (B).

Distribution: on Dichanthium foveolatum (Poaceae). Sporisorium foveolati is known only from Africa (Algeria, Cape Verde, Chad, Congo, Eritrea, and Morocco) (Vánky 2011; Vánky et al. 2011). It is reported here for the first time from the Canary Islands and Somalia.

Note. The description of Sporisorium foveolati is based on re-examination of the type: ALGERIA, in the mountains of C Sahara, Tefedest, Oued Araghan, 10 Apr 1928, R. Maire, Herb. Maire 9455 (H.U.V. 13 201, isotype). Morphologically, the specimens from the Canary Islands and Somalia fit well with this description.

Sporisorium lanigeri (Magnus) Ershad, Iran. J. Pl. Pathol. 33: 59, 1998.

Figs 9-12

Sori destroying all racemes of an infected inflorescence, cylindrical, 5-10 $\times 1-2$ $\mathrm{mm}$, tapering toward the apex, partly concealed by the spatheoles; initially covered by a thick, yellow-brown peridium that later ruptures irregularly, exposing a semi-agglutinated, dark reddish brown mass of spores and sterile cells, surrounding a single, stout, tapering columella with longitudinal furrows. The columella extends reaching up to $15 \mathrm{~mm}$. Sterile cells single or in small irregular groups, subglobose, broadly ellipsoidal or irregular, often collapsed, (9-)10.5-20(-23) $\mu \mathrm{m}$ long, larger than the spores, hyaline or subhyaline; wall $0.8-1.5 \mu \mathrm{m}$ thick. Spores subglobose, globose, broadly ellipsoidal or ovoid, sometimes ellipsoidal or slightly irregular, $(5-) 5.5-8(-8.5) \times(4.5-) 5.0-7.5(-8)(6.9 \pm 0.6 \times 6.3 \pm 0.6)$ $\mu \mathrm{m}(\mathrm{n}=100)$, medium yellow-brown to medium reddish brown; wall slightly uneven, 0.6 $1.0(-1.2) \mu \mathrm{m}$ thick, minutely verruculose, spore profile not affected or slightly affected. In SEM minutely echinulate-verruculose, main ornaments up to $0.2(-0.3) \mu \mathrm{m}$ high; spore surface punctate between the main ornaments.

Specimen examined - On Cymbopogon pospischilii (K. Schum.) C.E. Hubb.: SOMALIA, Asha Ufeyn, 5 Dec 1987, leg. B. Gabriel (B).

Distribution: on Cymbopogon spp. (Poaceae). This smut fungus is known from Africa (Algeria, Chad, Eritrea, Mali, Morocco, S. Africa, Sudan, and Zimbabwe), Asia, and Australia (Vánky 2011; Vánky et al. 2011). Sporisorium lanigeri is reported here for the first time from Somalia. Cymbopogon pospischilii is a new host of this smut fungus.

Urocystis corsica (Mayor \& Terrier) Vánky, Publ. Herb. Univ. Uppsala 9: 12, 1982.

Figs 13-16

Sori in uppermost leaves and aborted inflorescence as long striae between the veins, initially covered by the epidermis, which later ruptures disclosing the powdery, blackish brown mass of spore balls. Spore balls subglobose, broadly ellipsoidal, irregular or ovoid, sometimes ellipsoidal or elongated, composed of $(3-) 5-12(-18)$ central spores, $(3=$ $1.0 \%, 4=3.8 \%, 5=7.7 \%, 6=9.1 \%, 7=15.8 \%, 8=18.2 \%, 9=13.0 \%, 10=8.8 \%$, $11=7.7 \%, 12=4.6 \%, 13=2.8 \%, 14=2.5 \%, 15=2.1 \%, 16=1.8 \%, 17=0.7 \%$, $18=0.4 \%)(\mathrm{n}=285)$, surrounded by continuous layer of sterile cells; $(30-) 35-60(-67)$ 


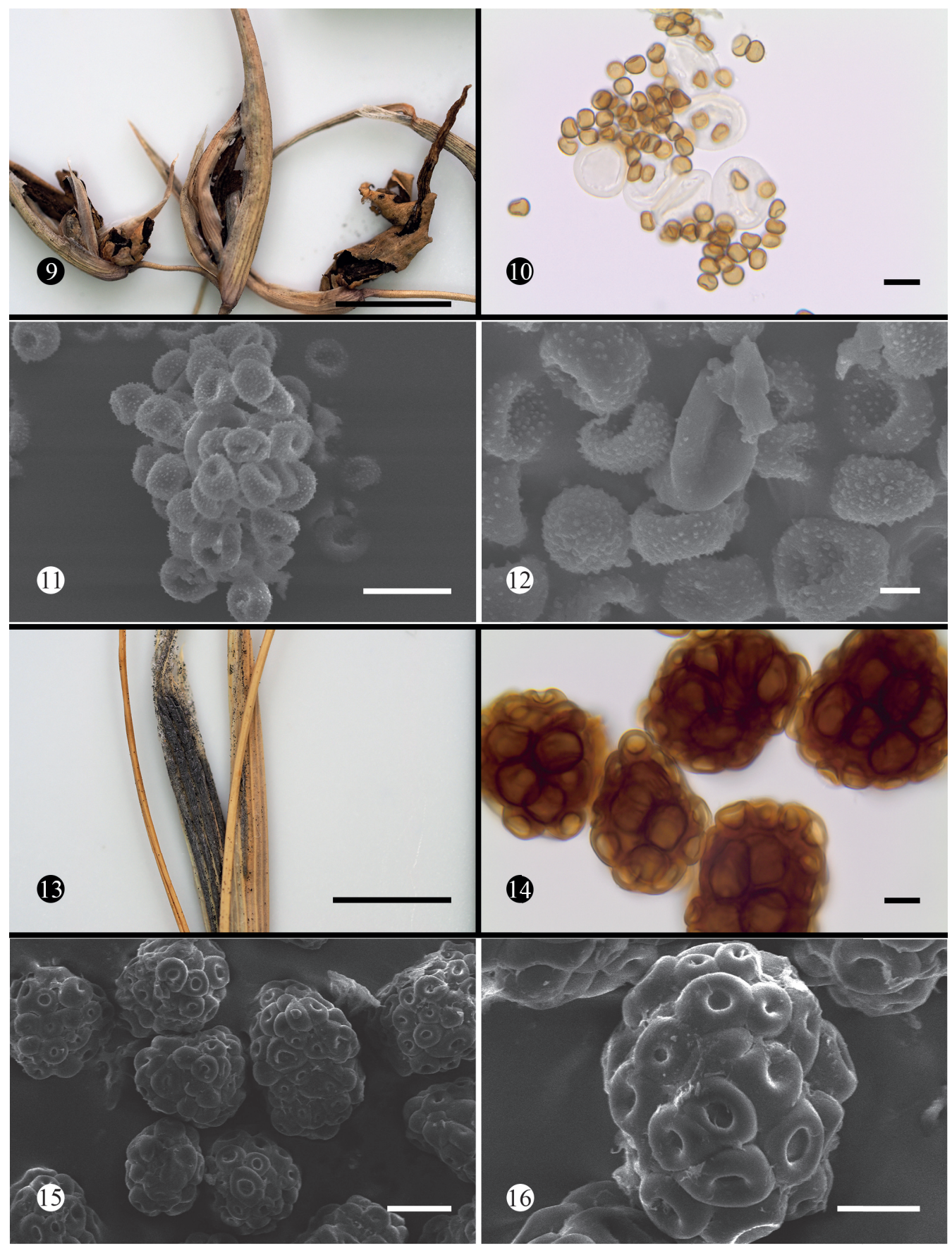

Figs 9-12. Sporisorium lanigeri (B). 9. Habit. 10. Spores and sterile cells in LM. 11, 12. Spores in SEM. Figs 13-16. Urocystis corsica (B). 13. Habit. 14. Spore balls in LM. 15, 16. Spore balls in SEM. Scale bars: 9, $13=0.5 \mathrm{~cm}, 10,11,14=10 \mu \mathrm{m}, 12=2 \mu \mathrm{m}, 15=20 \mu \mathrm{m}$ 


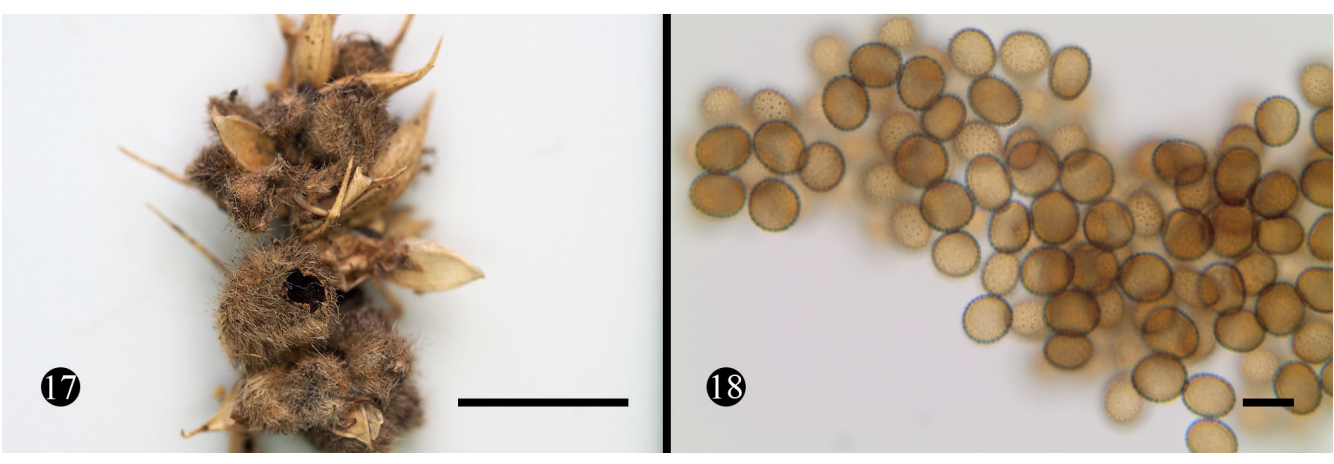

Figs 17, 18. Ustilago trichophora (B). 17. Habit. 18. Spores in LM. Scale bars: $17=0.5 \mathrm{~cm}$, $18=10 \mu \mathrm{m}$

$\times(27-) 30-43(-51) \mu \mathrm{m}$. Sterile cells variable in shape and size, suborbicular, broadly elliptical, irregular, irregularly elongated, elliptical or ovate in outline, usually collapsed, (5-)6-17(-21) $\mu \mathrm{m}$ long, medium yellow-brown; wall on the distal to the spores side 0.6$1.5 \mu \mathrm{m}$ thick, on the proximal and lateral to the spores sides much thicker (up to $4.5 \mu \mathrm{m}$ thick). In SEM smooth. Spores broadly ellipsoidal, subglobose, subpolyhedral, ellipsoidal, elongated or cuneate, sometimes slightly flattened on a few places, (11-)12-18(-20) $\times$ $10-14(-15.5)(14.4 \pm 1.4 \times 12.1 \pm 1.0) \mu \mathrm{m}(\mathrm{n}=100)$, dark reddish brown; wall slightly uneven, 0.7-1.2(-1.5) $\mu \mathrm{m}$ thick.

Specimen examined-On Stipellula capensis (Thunb.) Röser \& Hamasha (Stipa capensis Thunb.): CANARY ISLANDS, 31 Mar 2006, I. Scholz (B).

Distribution: on Stipellula capensis (Poaceae). Urocystis corsica has been previously recorded from South Europe (mainland Spain, Corsica, Crete, and Rhodes), North Africa (Morocco, Tunisia), West Africa (Mauritania), and Middle East (Iran) (Vánky 1985; Almaraz 1999; Vánky et al. 2011; Vánky \& Abbasi 2013). It is reported here for the first time from the Canary Islands.

Ustilago trichophora (Link) Kunze, Flora 13: 369, 1830.

Figs 17, 18

Specimen examined - On Echinochloa stagnina (Retz.) P. Beauv.: ZAMBIA, Namwala, 10 Mar 1961, leg. B.L. Mitchell, no. 6/26 (B).

Echinochloa stagnina is reported here for the first time as a host plant of Ustilago trichophora in Africa (cf. Zambettakis 1971: 269; Vánky et al. 2011: 72).

Acknowledgements. This research received support (grant no. DE-TAF-4056) from the SYNTHESYS Project http://www.synthesys.info/, financed by the European Community Research Infrastructure Action under the FP7 “Capacities” Program. We are grateful to the curators of the cited herbaria. The assistance of Dr Harrie J.M. Sipman (Botanic Garden and Botanical Museum Berlin-Dahlem) is kindly acknowledged. 


\section{References}

Almaraz, T. 1999. Fragmenta chorologica occidentalia, Fungi, 6918-6935. - Anales Jardín Botánico de Madrid 57: 141-142.

Denchev, T.T., Denchev, C.M., Michikawa, M. \& Kakishima, M. 2013. The genus Anthracoidea (Anthracoideaceae) in Japan and some adjacent regions. - Mycobiota 2: 1-125. http://dx.doi. org/10.12664/mycobiota.2013.02.01

Vánky, K. 1985. K. Vánky, Ustilaginales exsiccata. (No. 1-500). General index. - Publications from the Herbarium Ustilaginales Vánky (HUV) 2: 1-40.

Vánky, K. 2011. Smut fungi of the world. APS Press, St. Paul, Minnesota, USA.

Vánky, K. \& Abbasi, M. 2013, Smut fungi of Iran. - Mycosphere 4: 363-454. http://dx.doi.org/10.5943/ mycosphere/ $4 / 3 / 2$

Vánky, K., Vánky, C. \& Denchev, C.M. 2011. Smut fungi in Africa - a checklist. - Mycologia Balcanica 8: $1-77$.

Zambettakis, C. 1971. Les Ustilaginales des plantes d'Afrique. Reprint from the Bulletin de la Société Mycologique de France 86. Paris, 388 pp. 